\title{
A Review on Effect of Plant Growth Regulators on Physico-Chemical Attributes of Phalsa (Grewia subinaequalis D.C.)
}

\author{
Ashok Kumar Meena*, A. K. Singh and Bhujbal Singh \\ Department of Horticulture, College of Horticulture and Forestry, Narendra Deva University of \\ Agriculture and Technology, Narendra nagar (Kumarganj), Faizabad-224 229 (U.P.) India \\ *Corresponding author
}

\begin{tabular}{|c|c|}
\hline \multicolumn{2}{|r|}{ ABSTRACT } \\
\hline & \multirow{6}{*}{ 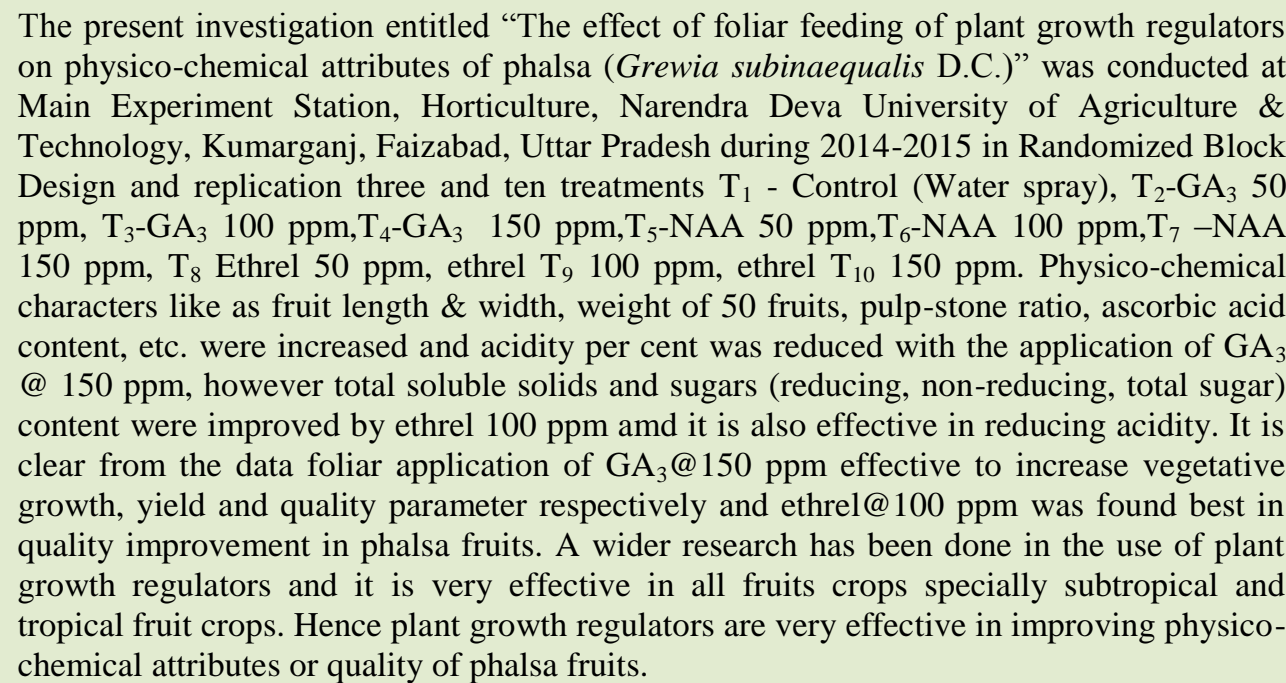 } \\
\hline Keywords & \\
\hline $\begin{array}{l}\text { Phalsa, } \\
\text { Physico-chemical } \\
\text { attributes, } \\
\text { Plant growth } \\
\text { regulators }\end{array}$ & \\
\hline Article Info & \\
\hline & \\
\hline & \\
\hline
\end{tabular}

\section{Introduction}

Phalsa (Grewia subinaequalis D.C.) is a subtropical fruit belongs to family Tiliaceae and its fruit are known as berry. Phalsa is a quick growing very hardy shrub which thrives well in arid and semi-arid region as well as in salt affected wasteland condition. It has high nutritional value, containing mineral like iron, phosphorus and vitamins like $\mathrm{A}$ and $\mathrm{C}$ having, 50-60 per cent juice, 10-11 per cent sugar. The fruits are very delicious, tasty and used as table purpose. The fruits are excellent for making juice and squash, ready to serve, nectar, syrup. However, it is mostly used as fresh fruit and has cooling effect. Application of growth substances viz., auxins and gibberellins has been effective in increasing fruit set and yield in several fruit crops including phalsa. Characteristics of fruits such as length, width, pulp-stone ratio and weight of 50 fruits were increased due to foliar feeding plant growth regulators and they can also improve fruit quality, plant growth regulators improve better formation and translocation of food, hormonal signaling by gibberellins, similar results were found by Chandra et al., 2015. Gibberellins decreases 
in acidity due to hormones application [might be due to increase translocation of carbohydrates and increase metabolism due to conversion of acids to sugar. Gibberellins improved quality of fruits supported by many researches in fruit crops such as Yadav et al., (1974), Singh et al., (1977), Grewal et al., (2000), Sharma et al., (2002), Young et al., (2003), Yadav et al., (2005), Kher, (2005), Singh et al., (2011) and Byas et al., (2014)].

Plant growth regulators signaling the various metabolic processes in plants such as apical dominance, inhibition of apical dominance, regulating flowering and early ripening by using ethrel in less amounts is very effective. Plant growth regulators can also increase the ascorbic acid content in fruits by synthesis of catalytic activity of several enzymes and coenzymes which are essential in ascorbic acid synthesis. So that plant growth regulators may improve physico-chemical characters like as fruit length $\&$ width, weight of 50 fruits, pulpstone ratio, ascorbic acid content, total soluble solids, sugars through better formation and translocation of carbohydrates, starch hydrolysis and early maturation phalsa fruits by ethrel Kacha et al., (2014). Hence plant growth regulators are very effective in improving physico-chemical attributes or quality of phalsa fruits (Bankar et al., 1990; Chundawat et al., 1973; Ray et al., 1992; Byas et al., 2014; Yadav et al., 2011; Ahmed et al., 2012; Agarwal et al., 2010; Ghosh et al., 2009; Kumar, 2010; Garasiya et al., 2013; Karole et al., 2016). Review on physicochemical attributes of fruits: -

Randhawa and Sharma (1962) observed that spray of NAA at 25, 50 and $75 \mathrm{ppm}$ on sweet orange (Citrus sinensis Osbeck) var. Jaffa, pineapple and Mosambi increased the fruit size. Prasad and Bajpai (1963) found that spray of NAA with concentrations of 25-75 ppm at full bloom stage and again 10days later on phalsa (Grewia asiatica L.) var. Sharbati increased fruit size, while, maximum diameter was obtained with 50ppm NAA.

Prasad and Jauhari (1963) reported that spraying of NAA and 2,4,5-T ranging from $10-100 \mathrm{ppm}$ on 16 year old tree of litchi (branches of newly fruit set) at $1^{\text {st }}$ April and 15 days later improved fruit size.

Prasad and Prasad (1966) reported that $\mathrm{GA}_{3}$ and NAA each 25, 50 and $100 \mathrm{ppm}$ concentration were applied on the plant of grape at full bloom and fruit setting stage. Among these $\mathrm{GA}_{3} 100 \mathrm{ppm}$ was the best treatment for improved the TSS content.

Srivastava and Singh (1969) observed that application of $\mathrm{GA}_{3}$ at $25 \mathrm{ppm}$ and $50 \mathrm{ppm}$ of litchi, 4 weeks after fruit set, increased the TSS content.

Veera and Das (1971) reported that mangoes cv. Banganpalli was sprayed with NAA and $\mathrm{GA}_{3}$ each at 10, 20 and 40, ppm concentration. All the concentration increased TSS content and greatest increased was found with spraying of $40 \mathrm{ppm}$ NAA.

Prasad and Pathak (1972) found that newly set mango fruits were sprayed with NAA at 25 , 50, 75 and $100 \mathrm{ppm}$. All treatments increased the total soluble solids. The lowest concentration $25 \mathrm{ppm}$ was most effective.

Yadav and Pandey (1974) observed that application of $\mathrm{GA}_{3}$ increase the bunch weight in grape without deteriorating the fruit quality.

Singh et al., (1977) reported that mango fruit weight was increased by the application of $\mathrm{GA}_{3}$, NAA and 2,4 5-T each at 50,100 and 250 ppm Concentration. Rahman et al., (1980) reported that pineapple plant cv. Giant kew, were treated with NAA at $0-80 \mathrm{ppm}$ gave increase fruit weight as compared to control. 
Biswas et al., (1988) also reported that the TSS increased due to its action on converting complex substances into simple ones, which enhances the metabolic activity in guava fruits.

Rema and Sharma (1991) reported significantly maximum fruit weight and volume with the application of $150 \mathrm{ppm}$ NAA or $480 \mathrm{ppm}$ Ethrel [ethephon] + $150 \mathrm{ppm}$ NAA during full bloom, whereas total soluble solids was also recorded with the $480 \mathrm{ppm}$ Ethrel during full bloom, as well as after applying 920 ppm Ethrel or 960 ppm Ethrel + $2.5 \mathrm{ppm} 2,4 \mathrm{D}$ one week before harvesting in phalsa fruit.

Brahmachari and Rubi (2000) stated that spraying of $\mathrm{GA}_{3}$, Kinetin and Melic Hydrazide increase fruit retention and reduced fruit drop in litchi cv. Purbi.

Brahmachari and Rubi (2001) advocated that foliar application of 2, 4,5-T (50-100 ppm), $\mathrm{GA}_{3}$ (100-200 ppm), CCC (500-1000) Cu $\left(\mathrm{NO}_{3}\right)_{2}$ and $\mathrm{CuCl}_{2} \quad(82 \%)$ increased fruit retention.

Ingle et al., (2001) reported that foliar application of 2, 4-D (10 ppm) NAA (30 ppm) and Gibberellic acid (25 ppm) with dry grass mulching increased the number of fruit of Nagpur mandarin.

Young et al., (2003) noted that foliar application of $\mathrm{GA}_{3}$ (at $0,25,50$ and 100 $\mathrm{mg} /$ liter) in Satsuma mandarin, improved physico-chemical attributes.

Sharma et al., (2002) observed that foliar application of zinc sulphate $(0.25$ or $50 \%), 2$, 4, 5-T (10 and $20 \mathrm{ppm}$ ) and $\mathrm{GA}_{3}$ (25 or 50 $\mathrm{ppm}$ ) increased the fresh weight, fruit volume, juice content, number of seeds per fruit, acidity, ascorbic acid content and total soluble solids of Kagzi lime.
Sharma et al., (2003) noted that foliar application of $\mathrm{ZnSO}_{4}(0.25$ and $0.50 \%), 2,4$, 5-T (10 and $20 \mathrm{ppm}$ ) and/or $\mathrm{GA}_{3}$ (25 and 50 $\mathrm{ppm}$ ) increased the fresh weight, volume and number of seeds per fruit in Kagzi lime.

Bhati and Yadav (2005) reported that foliar application of Urea 2 per cent and NAA at 20 ppm, in ber cv. Gola, increased fruit length, fruit breadth, fruit weight and pulp-stone ratio

Kher et al., (2005) observed that foliar application of $\mathrm{GA}_{3}(30,60,90$ and $120 \mathrm{ppm})$, CCC (300, 600, 900 and 1200 ppm) and NAA (20, 40, 60 and $80 \mathrm{ppm})$ effective to increase fruit weight, specific gravity firmness, total soluble solids, total sugars, reducing sugar and minimum acidity content in guava cv. Sardar.

Prasad et al., (2006) observed that foliar application of NAA at 10, 20, 30 and $40 \mathrm{ppm}$, 2,4-T at 10, 20, 30 and $40 \mathrm{ppm}, 2,4,5-\mathrm{T}$ at 20, 40, 60 and $80 \mathrm{ppm}, \mathrm{GA}_{3}$ at 50, 100, 150 and $200 \mathrm{ppm}$ improved the flowering behavior, fruit set and fruit retention of mango.

Dutta and Banik (2007) revealed that foliar feeding of nutrients and plant growth regulators significantly increased the fruit length, diameter, individual fruit weight and ultimately crop yield of guava. Maximum $(6.24 \mathrm{~cm})$ fruit length was obtained with treatment of urea $+\mathrm{K}_{2} \mathrm{SO}_{4}+\mathrm{ZnSO}_{4}+\mathrm{NAA}$ followed by urea $+\mathrm{K}_{2} \mathrm{SO}_{4}+\mathrm{ZnSO}_{4}$.

Singh et al., (2009) obtained maximum fruit yield as well as physico-chemical quality with foliar application of $\mathrm{GA}_{3}(50 \mathrm{ppm})+2$, 4-D (10 ppm) +urea $2 \%$ followed by $\mathrm{GA}_{3}$ (50 ppm) + NAA (15 ppm + urea $2 \%$ ) on aonla. Katiyar et al., (2010) reported that foliar sprays of 25 and 30 ppm NAA and $\mathrm{GA}_{3}$ in conjunction with urea were improved fruit size, maximum T.S.S. and sugar content of ber cv. Banarasi Karaka. 
Debnath et al., (2011) reported that the influence of NAA @ 25 and @ 50 ppm, GA 3 @50 and@100 ppm, kinetin@15 and@50 ppm, ethrel@250 and@500 ppm on yield and quality parameters of phalsa (Grewia subinaequalis DC). Among all the treatments, GA3 @ 100 ppm was note most effective to improving yield per plant $(3.05 \mathrm{~kg})$, and per hectare $(7.63 \mathrm{t})$ and hundred fruit weight (61.48 g). Ethrel 500 ppm recorded maximum total soluble solids content (25.72\%). Maximum reducing sugar $(18.91 \%)$, TSS to acid ratio (10.98), pulp weight (51.45 g), pulp to stone ratio $(5.85 \mathrm{~g})$ and minimum titratable acidity (2.26\%) and stone weight (8.83 g) was recorded with $\mathrm{GA}_{3} @ 100$ ppm. Kinetin @ 30 ppm recorded maximum shelf life $(51.46 \mathrm{hr})$ of the fruits.

Anawal et al., (2015) indicated that NAA 40 ppm was found effective in increasing number of fruits per tree (62.44), fruit length (8.66 $\mathrm{cm})$, fruit diameter $(8.71 \mathrm{~cm})$, fruit weight $(262.23 \mathrm{~g})$, fruit volume $(255.44 \mathrm{ml})$, TSS $\left(16.76^{\circ} \mathrm{B}\right)$, total sugars $(15.58 \%)$, reducing sugars $(13.83 \%)$, non-reducing sugars (1.75 $\%)$ against control in the pomegranate $\mathrm{cv}$. Bhagwa.

Singh et al., (2015) conducted that the effect of pruning intensity, foliar feeding of P.G.R. and micro nutrients on physico-chemical attributes of phalsa (Grewia subinaequalis) fruits. Significantly higher fruit size (length and breadth) was analyzed by foliar spray of ZnSO4@0.4 per cent. The maximum weight of fifty fruits was recorded with foliar feeding of $\mathrm{ZnSO} 4$ @ 0.4 per cent. Significantly higher TSS value in fruits was analyzed by foliar spray of $\mathrm{ZnSO} 40.4$ per. The maximum reducing, non-reducing and total sugars have been observed with foliar spray of $\mathrm{ZnSO} 40.4$ per cent reduction in acidity of fruit was observed with the foliar spray of $\mathrm{ZnSO} 40.4$ per cent. The foliar spraying of $\mathrm{ZnSO} 40.4$ per cent was found significantly most effective in increasing ascorbic acid content of fruit.
Chandra et al., (2015) observed that the spray of $\mathrm{GA}_{3}$ had maximum impact to increase the size, weight and volume of fruit. However, the NAA @ 50 ppm was found to increase the pulp thickness, while the maximum weight of pulp was found when the trees are treated with the combined spray of NAA + 2, 4-D 25 ppm $\left(\mathrm{T}_{6}\right)$. The yield per treatment and TSS of fruit was appreciably influenced by all the growth regulators over control. However, the maximum impact $(21.67 \mathrm{~kg}$ yield and 10.02 ${ }^{0}$ Brix TSS) was recorded under T9 treatment (2, 4-D $50 \mathrm{ppm}$ ). The maximum acidity (1.86 $\%)$ was found under $\mathrm{T} 7$ treatment, spray of GA3 $50 \mathrm{ppm}$. The Vitamin C content of fruits was recorded maximum $(563.44 \mathrm{mg} / 100 \mathrm{~g})$ under T6 treatment (NAA + 2, 4-D 25 ppm). From the findings of present study, it might be concluded that spray of growth regulators like GA3, NAA and 2, 4-D alone or in combination may increase the yield and quality of aonla.

Rokaya et al., (2016) revealed that the fruits treated with $\mathrm{GA}_{3}$ at $20 \mathrm{ppm}$ retained higher fruit weight (128.6 g), more firmness (3.54 $\mathrm{kg} / \mathrm{cm}^{2}$ ), better juice recovery $(57.75 \%)$, and greater TSS/acid ratio (21.24) at the end of study (20 December). The PLW was found less with $\mathrm{GA}_{3}$ at $30 \mathrm{ppm}$ in both ambient $(5.17 \%)$ and cellar $(6.69 \%)$ condition as against untreated fruits $(9.52 \%$ and $11.76 \%)$. Similarly, the decay loss was minimum in the fruits treated with $\mathrm{GA}_{3}$ at $30 \mathrm{ppm}$ both with ambient $(1.02 \%)$ and cellar condition $(8.21 \%)$ as against control with ambient $(5.54 \%)$ and cellar $(21.58 \%)$ in guava.

Rajput et al., (2015) concluded that the treatment $\mathrm{T}_{10}(0.2 \%$ boron + GA3 $60 \mathrm{ppm}+$ NAA $150 \mathrm{ppm}+$ ethrel $750 \mathrm{ppm}$ ) was found best for physical parameters and treatment $\mathrm{T} 5(0.2 \%$ boron + NAA $150 \mathrm{ppm})$ for yield point of view, while for quality point of view the treatment $\mathrm{T}_{9}(0.2 \%$ boron + ethrel 1000 ppm) was found best. As far as the relative 
economics of the treatment is concerned, the maximum net realization of Rs. 1,72,807 per hectare with highest 1:6.6 cost benefit ratio (CBR) was obtained by the treatment $\mathrm{T}_{5}$
$(0.2 \%$ boron + NAA $150 \mathrm{ppm})$ as compared to other treatments. Therefore, the treatment $\mathrm{T}_{5}(0.2 \%$ boron + NAA $150 \mathrm{ppm})$ is best among all treatment for higher production.

Table.1 Various treatment effects on physic-chemical properties of fruits

\begin{tabular}{|c|c|c|c|c|c|c|c|c|c|c|}
\hline Treatments & $\begin{array}{l}\text { Fruit } \\
\text { length }\end{array}$ & $\begin{array}{l}\text { Fruit } \\
\text { width }\end{array}$ & $\begin{array}{l}\text { Pulp/ } \\
\text { stone } \\
\text { ratio }\end{array}$ & $\begin{array}{l}\text { Weight } \\
\text { of fifty } \\
\text { fruits(g) }\end{array}$ & $\begin{array}{l}\text { TSS }^{\circ} \\
\text { Brix }\end{array}$ & $\begin{array}{l}\text { Total } \\
\text { sugars }\end{array}$ & $\begin{array}{l}\text { Non- } \\
\text { reducing } \\
\text { sugars }\end{array}$ & $\begin{array}{l}\text { Reducin } \\
\text { g sugars } \\
(\%)\end{array}$ & $\begin{array}{l}\text { Acidity } \\
(\%)\end{array}$ & $\begin{array}{l}\text { Ascorbic } \\
\text { acid } \\
\text { content }\end{array}$ \\
\hline $\begin{array}{l}\mathrm{T}_{1} \\
\text { Control(wat } \\
\text { er spray) }\end{array}$ & 0.88 & 1.07 & 1.05 & 29.94 & 18.98 & 16.98 & 2.96 & 13.71 & 2.56 & 26.00 \\
\hline $\begin{array}{l}\mathrm{T}_{2} \mathrm{GA}_{3} @ \\
50 \mathrm{ppm}\end{array}$ & 0.94 & 1.13 & 1.17 & 42.00 & 20.33 & 17.70 & 3.05 & 14.48 & 2.37 & 37.33 \\
\hline $\begin{array}{l}\mathrm{T}_{3} \mathrm{GA}_{3} @ \\
100 \mathrm{ppm}\end{array}$ & 0.96 & 1.14 & 1.21 & 43.00 & 20.58 & 18.16 & 3.34 & 14.58 & 2.35 & 38.67 \\
\hline $\begin{array}{l}\mathrm{T}_{4} \mathrm{GA}_{3} @ \\
150 \mathrm{ppm}\end{array}$ & 0.97 & 1.15 & 1.21 & 43.53 & 20.33 & 18.23 & 3.56 & 14.63 & 2.29 & 40.00 \\
\hline $\begin{array}{l}\mathrm{T}_{5} \text { NAA @ } \\
50 \text { ppm }\end{array}$ & 0.91 & 1.12 & 1.2 & 40.66 & 20.95 & 17.77 & 3.24 & 14.40 & 2.39 & 37.67 \\
\hline $\begin{array}{l}\mathrm{T}_{6} \text { NAA @ } \\
100 \text { ppm }\end{array}$ & 0.93 & 1.13 & 1.19 & 42.33 & 21.20 & 18.23 & 3.68 & 14.37 & 2.42 & 36.67 \\
\hline $\begin{array}{l}\mathrm{T}_{7} \mathrm{NAA} @ \\
150 \mathrm{ppm}\end{array}$ & 0.95 & 1.14 & 1.19 & 43.33 & 21.45 & 17.68 & 3.28 & 14.23 & 2.43 & 35.33 \\
\hline $\begin{array}{l}\mathrm{T}_{8} \text { Ethrel @ } \\
50 \text { ppm }\end{array}$ & 0.91 & 1.11 & 1.16 & 39.67 & 22.17 & 19.57 & 4.13 & 15.15 & 2.35 & 34.00 \\
\hline $\begin{array}{l}\mathrm{T}_{9} \text { Ethrel @ } \\
100 \mathrm{ppm}\end{array}$ & 0.90 & 1.05 & 1.16 & 35.67 & 23.60 & 19.88 & 4.24 & 15.42 & 2.32 & 33.67 \\
\hline $\begin{array}{r}\mathrm{T}_{10} \text { Ethrel } \\
\text { @ } 150 \mathrm{ppm} \\
\end{array}$ & 0.89 & 1.03 & 1.17 & 33.00 & 22.58 & 19.72 & 4.21 & 15.33 & 2.32 & 33.33 \\
\hline SEm \pm & 0.01 & 0.01 & 0.01 & 0.46 & 0.39 & 0.23 & 0.08 & 0.08 & 0.03 & 0.53 \\
\hline C. D. & 0.03 & 0.03 & 0.03 & 1.38 & 1.18 & 0.70 & 0.24 & 0.27 & 0.09 & 1.59 \\
\hline
\end{tabular}

\section{Materials and Methods}

Twenty years old phalsa plants were selected for at Main Experimental Station, Department of Horticulture, Narendra Deva University of Agriculture and Technology, Kumarganj, Faizabad (U.P.) during the year 2014-15. The experiment was laid out in a Randomized Block Design with ten treatments and replicated thrice. The treatments consisted of three levels each of gibberellic acid 50, 100 and $150 \mathrm{ppm}$, naphthalene acetic acid 50, 100 and 150 ppm, ethrel 50, 100 and $150 \mathrm{ppm}$ and control. The growth regulators were applied twice i.e., first spray at pre-bloom and second spray just after fruit set. The length and breadth of fruits were recorded at the colour break stage with the help of vernier callipers. The pulp: stone ratio was calculated in relation to pulp and stone weight, weight of 50 fresh fruits have been taken by electronic balance and chemical analysis was done to determine quality parameters of the fruit.

\section{Results and Discussion}

The maximum fruit size was observed with foliar spray of $\mathrm{GA}_{3} 150 \mathrm{ppm}$. These can be attributed to nature of gibberellins to increase the vegetative growth due to which more food 
material might be made available to the developing fruits. These results are in close conformity with findings of Chandra et al., (2015) with the spray of GA G $_{3}$ in anola and Singh et al., (2015) in phalsa and Kundu et al., (2013) in pear with application of Gibbrellin and also reported by Brahmchari et al., in1996 fruit length, diameter, weight of litchi cv. Purbi highest with $\mathrm{GA}_{3} 50 \mathrm{ppm}$. The highest pulp: stone ratio was measured with foliar spray of $\mathrm{GA}_{3} 150 \mathrm{ppm}$. The results are in close conformity with the findings of Kumar et al., (2014) in phalsa. The results of experiment indicated that the weight of 50 fruits $(43.53 \mathrm{~g})$ was recorded maximum in treatment $\mathrm{GA}_{3} 150$ ppm followed by NAA @ 150 ppm (43.33) and $\mathrm{GA}_{3} 100$ ppm (43.00), It may be due to the involvement of $\mathrm{GA}_{3}$ to increase the cell division and translocation of food material which might be responsible to improve the weight of fruits, similar effects observed by Kher et al., (2005) in guava, Kacha et al., 2014 in phalsa, Chandra et al., (2015) in aonla fruits and Singh et al., (2015).

The TSS was significantly increased (25.23 $\%$ ) with treatment of ethrel @ 100 ppm followed by ethrel $150 \mathrm{ppm}$. The increase in total soluble solids and sugar percentage may be caused due to better formation and translocation of carbohydrates, starch hydrolysis and early maturation of fruits. The present findings are in conformity with those reported by Sandhu and Bal (1989) in ber, Biswas et al., (1988) in guava, Goswami et al., 2013 in pomegranate. Kacha et al., (2014) in phalsa also reported increased TSS and sugars with ethrel $1000 \mathrm{ppm}$ followed by ethrel $750 \mathrm{ppm}$. The reducing sugars, nonreducing sugar and total sugars contents in fruit juice of phalsa have been increased significantly by plant growth regulators Similar findings were also reported by Brahmachari et al., (2000) in guava, Goswami et al., 2013 in pomegranate and by Sandhu and Bal 1989 in ber (400 ppm ethrel), Kacha et al., (2014) in phalsa.GA 3150 ppm was found superior in decreasing acidity followed by $\mathrm{GA}_{3} 50 \mathrm{ppm}$. The reason for decrease in acidity due to hormones application $\left(\mathrm{GA}_{3}\right.$ and NAA) might be due to increase translocation of carbohydrates and increase metabolism due to conversion of acids to sugar. The results revealed that $\mathrm{GA}_{3} 150 \mathrm{ppm}$ significantly increased. Ascorbic acid (39.20 mg/100g), It might be due to increase in synthesis of catalytic activity of several enzymes and coenzymes which are instrumental in ascorbic acid synthesis, close conformity to Kher et al., (2005) in guava and Kacha et al., (14) in phalsa. Ethrel (100 ppm) was found effective improving the fruit quality of phalsa confirming to results of Kacha et al., (2014) in phalsa.

\section{References}

Agrawal, S. and Dikshit, S.N. 2010. Studies on the effect of plant growth regulators on qualitative characters of sapota $\mathrm{cv}$. Cricket Ball. Indian J. Hort., 67(2): 177-180.

Ahmed, W., Tahir, F.M., Rajwana, I.A., Raza, S.A. and Asad, H.U. 2012. Comparative evaluation of plant growth regulators for preventing premature fruit drop and improving fruit quality parameters in "Dushehri" mango. Food Sci. Technol. Abs. Intern. J. Fruit Sci., 12(4): 372389.

Anawal, V.V., Narayanaswamy, P. and Ekabot, S.D. 2015. Effects of Plant Growth Regulators on Fruit Set and Yield of Pomegranate Cv. Bhagwa, Int. J. Scientific Res., 4(9): 220-222.

Bal, J.S., Singh, S.N., Randhava, J. S. and Jowanda J.S. 1984. Effect of growth regulators on fruit drops size and quality of ber(Zizyphus mauritiana Lam K.) Ind. J. Hort., 41(3-4): 182-185.

Bankar, G.J. and Prasad, R.N. 1990. Effect of Gibberellic acid and NAA on fruit set 
and quality of fruit in ber cv. Gola. Prog. Hort., 22(1-4): 60-62.

Bhatia, B.S. and Yadav, P. K. 2005. Effect of foliar application of urea and NAA on fruit yield and quality of ber(Zizyphus mauritana Lamk.) Nati. Sem. on Commercialization of Horticultural in Non-traditional areas. Organized by Central Institute for Agric. Hort., Bikaner, (Rajasthan)5-6: 119.

Biswas, B., Ghosh, S.K., Ghosh, B. and Mitra, S.K. 1988. Effect of growth substances on fruit weight, size and quality of guava cv. L-49. Indian Agriculturist, 32(4): 245-248.

Biswas, B., Ghosh, S.K., Ghosh, B. and Mitra, S.K. 1988. Effect of growth substances on fruit weight, size and quality of guava cv. L-49. Indian Agriculturist, 32(4): 245-248.

Brahmchari, V.S. and Rani, R. 2001. Effect of growth substances on cracking and other physio-chemical composition of litchi, Orrisa J. Hort., 29(1): 41-45.

Bramhchari, V.S. and Rubi. 2000. Effect of growth substances on fruit yield and physico-chemical composition of litchi fruit. Prog. Hort., 32(1): 50-55.

Byas P.N. 2014. Studies on foliar application of micronutrients and $\mathrm{GA}_{3}$ on yield and quality of ber(Zizyphus mauritiana Lamk.) fruits cv. Gola. Thesis submitted to the Master of Science in Horticulture to N. D. Uni. of Agr. and Tech. Faizabad,(UP

Chandra, R. Manju, Rawat, S. S. and Singh, K.K. 2015. Effect of FoliarApplication of various Growth Regulators on Yield and Quality of Aonla cv. NA- 7. Int. J. Tropical Agr., 33(3): July-September.

Chandra, R., Manju, Rawat, S.S. and Singh, K.K. 2015. Effect of FoliarApplication of various Growth Regulators on Yield and Quality of Aonla cv. NA- 7. Int. J. Trop. Agr., 33(3).

Choudhary, H.D., Jain, M.C., Sharma, M.K. and Bhatnaga, P. 2013. Effect of plant growth regulators on growth and yield of nagpur mandarin(Citrus reticulata Blanco.. The Asian J. Horticulture, 8(2): 746-750.

Chundawat and Randhava. 1973. reported that the foliar application of $\mathrm{GA}_{3}, 2,4-\mathrm{D}$ and $2,4,5-\mathrm{T}$, increased the fruit set over control in grape fruit cv. Duncan. The best result was obtained with application $750 \mathrm{ppm} \mathrm{GA}_{3}$ and $10 \mathrm{ppm}$ 2, 4, 5-T.

Chundawat, B.S. and Randhawa, G.S. 1972. Effect of plant growth regulator on fruit set, drop and quality of Saharanpur Special variety of grape fruit(Citrus paradise L.. Indian J. Hort, 29(3-4): 77282

Debnath, A., Vanajalatha, K., Momin, U and Reddy, M. 2011. Effect of NAA, GA 3 , kinetin and ethrelon yield and quality in phalsa (Grewia subinaequalis DC. Asian J. Hort., 6(2): 474-477.

Garasiya, V.R., Patel, N.M., Bhadauria, H.S. and Wankhede, V.R. 2013. Effect of plant growth regulators on quality of winterseason guava(Psidium guajava L.) cv. L-49 Sardar. The Asian J. Hort.,

Gersthein, L.A. 1973. Studies on effect of gibberellin on citrus, fruit set and quality. SubdropichesKil-Kul-Tury., No. 4: 78-82.

Ghosh, S.N., Bera, B., Roy, S. and Kundu A. 2009. Effect of plant growth regulators in yield and fruit quality in pomegranate c.v. Ruby. J. Horticulture Sci., 4: 2 158160.

Goswami, J.D., Patel, N.M., Bhaduria, H.S. and Wankhade, V.R. 2013. To study the effect of plant growth regulators on quality traits of pomegranate cv. Sinduri. The Asian J. of Hort., 8(1): 361-363.

Goswami, J.D., Patel, N.M., Bhaduria, H.S. and Wankhade, V.R. 2013. To study the effect of plant growth regulators on 
quality traits ofpomegranate cv. Sinduri. The Asian J. of Hort., 8(1): 361-363.

Grewal, G.P.S., Singh, Z. and Singh, L. 2000. Effects of gibberellin A4/A7 and blossom thinning on fruit set, retention, quality, shoot growth and return bloom of phalsa (Grewia asiatica L.). Acta Hort., 525: 463-466.

Ingle, H.V., Rathod, N.G. and Patil, D.R. 2001. Effect of growth regulators and mulching on quality of Nagpur Mandrin. Annals of Pl. Physio., 15(1): $85-88$

Kacha, H.L., Jat, G. and Patel, S.K. 2014. Performance of various plantgrowth regulators on yield and quality of phalsa. Hort. Flora Res. Spectrum, 3(3): 292-294.

Kacha, H.L., Jat, G. and Patel, S.K. 2014. Performance of various plantgrowth regulators on yield and quality of phalsa. Hort. Flora Res. Spectrum, 3(3): 292-294.

Kacha, H.L.,Viradia, R.R., Leua, H.N., Jat Giriraj and A.K. Tank. 2012 Effect of NAA, GA 3 and ethrel on yield and quality of phalsa (Grewia asiatica L). The Asian J. Hort., 7(2): 242-245.

Kachare, D.B. and Bhosale, A.M. 2009. Effect of plant growth regulators and micro-nutrients on certain quality attributes of Kagzi lime(Citrus aurantifolla) Swingle. Int. J. Agr. Sci., 5: 50-52.

Karole, B. And Tiwari, R. 2016. Effect of preharvest spray of growth regulators and urea on growth, yield and quality of ber under malwa plateau conditions, Annals of Pla. and Soil Res., 18(1): 18-22.

Kher, R., Bhat, S. and Wali, V. K. 2005. Effect of foliar application of $\mathrm{GA}_{3}, \mathrm{NAA}$ on physico-chemical characteristics of guava cv. Sardar. Haryana J. Hort., 34(1/2): 31-32

Kumar, S., Singh, A.K. and Yadav, A.L. 2010. Effect of foliar application of
$\mathrm{GA}_{3}, \mathrm{NAA}, \mathrm{KNO}_{3}$ and Borax on fruit quality of rainy season guava $\mathrm{cv}$. Lucknow-49. Plant Archives, 10(1): 317-319.

Kundu, M., Joshi, R., Rai, P.N. and Bist, L. D. 2013. Effect of bio-regulators on fruit growth, quality and productivity of pear [Pyruspyrifolia(Brum) Nakai] cv Gola under tarai condition. J. Appl. Horticulture, 15(2): 106-109.

Kundu, M., Joshi, R., Rai, P.N. and Bist, L.D. 2013. Effect of bio-regulators on fruit growth, quality and productivity of pear [Pyruspyrifolia(Brum) Nakai] cv Gola under tarai condition. J. Appl. Horticulture, 15(2): 106-109.

Prasad, A. and Bajpai, P.N. 1963. Effect of Alpha NAA on fruit set, size responding and yield of phalsa var. sharbati. Kanpur Agri. college J., 22(1): 59-61.

Prasad, A. and Jahuhari, O.S. 1963. Effect of 2,4,5-T and NAA on fruit drop and size of litchi fruits. Madras Agri. J., 50: 2939.

Prasad, A. and Prasad, A. 1966. Foliar feeding of plant growth regulators in grape. Indian J. Hort., 30(1): 384-386.

Prasad, B., Ray, R.N., Prasad, K.K., Chowdhary, B.M. and Brahmachari, V.S. 2006. Effect of growth regulators on flowering, fruit set and fruit retention in Mango. J. Res., Birsa Agricultural University, 18(2): 257-260.

Rahman, M.A., Shahidullah, M. and Hoque M.S. 1980. The effect of different concentration of Alafa NAA on the quality characteristic of mature ripe pine apple. Bangladesh Council of Scientific and Industrial Research Labs., Dacca,14(1/2): 126 -136.

Rajput, R.P., Senjaliya, H.J., Vala, G.S. and Mangroliya, G.S. 2015. Effect ofvarious plant growth regulators on yield and quality of guava(Psidium guajava L.) cv. L-49. Int. J. Agr. Sci., 11(1): 179182. 
Ram, R.B., Pandey, S. and Kumar, A. 2005. Effect of plant growth regulators (NAA and $\mathrm{GA}_{3}$ ) on fruit retention, physicochemical parameters and yield of ber cv. Banarsi Karaka. Biochem. Cellular Archives, 5(2): 229-232.

Randhawa, G.S., Sharma, B.B. and Jain, M.L. 1962. Effect of plant growth regulators on fruit drop, size and quality in sweet orange var. Jaffa Pine Apple and mausambi. Indian J. Hort., 18: 177-180.

Ray, D.P., Singh S., P.K., Dora, D.K., Sahu, P. and Das, B.K. 1992. Effect of plant growth regulators on fruit set, retention, development and quality of sapota (Achraszapota L.) cv. Cricket ball. Food Sci. Tech. Abst., Indian Agriculturist, 36(1): 9-13.

Rema, J. and Sharma, V.P. 1991. Effect of plant growth regulators on yield and quality of phalsa (Grewia subinaequalis L.), Food Sci. Tech. Abst. South Indian Hort., 39(6): 327-331.

Rokaya, P.R., Baral, D.R., Gautam, D.M., Shrestha, A. K. and Paudyal, K.P. 2016. Effect of Pre-Harvest Application of Gibberellic Acid on Fruit Quality and Shelf Life of Mandarin (Citrus reticulata Blanco) American J. Pla. Sci., (07): 1-7.

Sandhu, S.S. and Bal, J.S. 1989. Effect of preharvest spray of ethephon onsize, quality and ripening of ber cv. Umran. Indian J. Hort., 46(1): 23-27.

Sandhu, S.S. and Bal, J.S. 1989. Effect of preharvest spray of ethephon onsize, quality and ripening of ber cv. Umran. Indian J. Hort., 46(1): 23-27.

Sandhu, S.S. and Bal, J.S. 1989. Effect of preharvest spray of ethephon on size, quality and ripening of ber cv. Umran. Indian J. Hort., 46(1): 23-27.

Sharma, A.K., Singh, K. and Mishra, S.P. 2002. Effect of foliar spray of zinc sulphate, 2,4,5-T and $\mathrm{GA}_{3}$ on quality of Kagzi lime(Citrus aurantifolia Swingle.
Orissa J. Horticulture, 30(2): 115-118. Sharma, A.K., Singh, K. and Mishra, S.P. 2003. Effect of foliar spray of zinc sulphate, 2,4,6-T and $\mathrm{GA}_{3}$ on quality of Kagzi lime (Citrus aurantifolia Swingle. Orissa J. Hort., 31(2): 29-32.

Singh, Ashutosh Kumar, Kumar, Anil and Yadav, A.L. 2015. Effect ofpruning intensity, foliar feeding of P.G.R. and micro nutrients on physico-chemical attributes of phalsa(Grewia subinaequalis) fruits, Res. Environ. Life Sci., 8(4): 675-67.

Singh, Ashutosh Kumar, Kumar, Anil and Yadav, A.L. 2015. Effect ofpruning intensity, foliar feeding of P.G.R. and micro nutrients on physico-chemical attributes of phalsa(Grewia subinaequalis) fruits, Res. Environ. Life Sci., 8(4): 675-67.

Singh, Ashutosh Kumar, Kumar, Anil and Yadav, A.L. 2015. Effect of pruning intensity, foliar feeding of P.G.R. and micro nutrients on physico-chemical attributes of phalsa (Grewia subinaequalis) fruits, Res. Environ. Life Sci., 8 b(4): 675-678.

Singh, G.C. and Singh, G. 1988. Effect of calcium nitrate and plant growth regulators on nutrient uptake by leaves and fruits on quality of guava. Prog. Hort., 20(34): 241-245

Singh, J.P., Kumar S., Katiyar P.N. and Dwivedi, A.K. 2011. Effect of calciumnitrate, $\mathrm{GA}_{3}$ and ethrel on fruiting, ripening and chemical traits of phalsa (Grewiasubinaequalis D.C.) Annals Hort., 4(1): 72-76

Singh, U.R., Tripathi, J.S. and Tripathi, B.M. 1977. Effect of Gibberellic Acid on size and quality of mango fruit. Punjab Hort. J., 17(3/4): 120-121.

Srivastava, C.P., Singh, H.K., Vishwanath and Pratap, Bhanu. 2009. Efficacy of foliar feeding of plant growth regulators along with urea on yield and quality of 
aonla (Emblica officinalis Gaertn. Cv. NA-7 fruits. Annals of Hort., 2(1): 7779.

Srivastava, R.P. and Singh, L. 1969. Effect of growth substances on the quality of Litchi. Hort. Sci., 1(2): 1-6.

Veera, S. and Das, R.S. 1971. Effect of plant growth regulators on development and quality of fruits in mango (Mangifera indica L.): South Indian Hort., 16(1/4): 29-35.

Yadav I.S. and Panday S.N. 1974. Effect of berry thinning and $\mathrm{GA}_{3}$ application on yield and quality of Pusa Seedless grapes (V. vinifera). Prog. Hort., 6: 3(81-87).

Yadav, B., Rana, G.A. and Bhati, S.K. 2005. Response of NAA, urea and $\mathrm{ZnSO}_{4}$ on fruit drop in ber (Zizyphus mauritiana Lamk.. Haryana J. Hort. Sci., 33(3/4): 181-182.

Yadav, D.N. and Chaturvedi, O.P. 2005. Influence of $\mathrm{GA}_{3}$ and trace elements on fruit drop, growth and quality of Ber (Zizyphusmauritiana Lamk.) cv. Banarsi Karaka. Farm Sci. J., 14(1): 2728.

Yadav, H.C., Yadav, A.L., Yadav, D.K. and Yadav, P.K. 2011. Effect of foliar application of micro-nutrients and $\mathrm{GA}_{3}$ on fruit yield and quality of rainy season guava (Psidium guajava L.)

Yadav, S., Bhatia, S.K., Godara, R.K. and Rana, G.S. 2001. Effect of growth regulators on the yield and quality of winter season guava cv. L-49. Haryana J. Hort. Sci., 30: (1-2) 1-2.

Young, M., Young, E.K., Ho Kim Chang Myung and Sangdok, K. 2003. Effects of foliar application of $\mathrm{GA}_{3}$ on flowering, vegetative shots, fruit set and fruit size and fruit quality of very earlymaturing Satsuma mandarin(Karan. Korean J. Hort. Sci. Tech., 21(2): 110123.

\section{How to cite this article:}

Ashok Kumar Meena, A.K. Singh and Bhujbal Singh. 2017. A Review on Effect of Plant Growth Regulators on Physico-Chemical Attributes of Phalsa (Grewia subinaequalis D.C.). Int.J.Curr.Microbiol.App.Sci. 6(5): 1929-1938. doi: https://doi.org/10.20546/ijcmas.2017.605.214 